\title{
Porphyry-related high-sulfidation mineralization early in Central American Arc development: Cerro Quema deposit, Azuero Peninsula, Panama
}

\author{
Mineralización de alta sulfuración en relación con pórfidos en el desarrollo del Arco \\ Centroamericano: El depósito de Cerro Quema, Península de Azuero, Panamá
}

José Perelló ${ }^{1, *}$, Alfredo García ${ }^{2}$, Robert A. Greaser ${ }^{3}$

${ }^{1}$ Antofagasta Minerals S.A., Apoquindo 4001, piso 18, Las Condes, Santiago, Chile.

${ }^{2}$ Avenida Kennedy 4820, departamento 42, Vitacura, Santiago, Chile.

${ }^{3}$ Department of Earth and Atmospheric Sciences, University of Alberta, Edmonton, T2G 2E3, Alberta, Canada.

* Corresponding author: (J. Perelló) jperello@aminerals.cl

\section{How to cite this article:}

Perelló, J., García, A., Creaser, R.A. ,2020, Porphyry-related high-sulfidation mineralization early in Central American Arc Development: Cerro Quema deposit, Azuero Peninsula, Panama: Boletín de la Sociedad Geológica Mexicana, 72(3), A260719. http://dx.doi.org/10.18268/ BSGM2020v72n3a260719

Manuscript received: March 12, 2019

Corrected manuscript received: June 15, 2019 Manuscript accepted: July 22, 2019

Peer Reviewing under the responsibility of Universidad Nacional Autónoma de México.

This is an open access article under the CC BY-NC-SA (https://creativecommons. org/licenses/by-nc-sa/4.0/)

\section{ABSTRACT}

The 70.74 to $70.66 \mathrm{Ma}$ age range for three molybdenite samples accompanying pyrite- and enargite-bearing assemblages effectively constrains an earliest Maastrichtian age for the high-sulfidation $\mathrm{Au}-\mathrm{Cu}$ mineralization at Cerro Quema, Panama. The epithermal system was contemporaneous with emplacement of a composite dacite dome complex in a geotectonic setting transitional from mafic, primitive intraoceanic (Azuero Protoarc) to more evolved island arc magmatism (Azuero Arc), during initial construction of the Central American land bridge at the trailing edge of the Caribbean Large Igneous Province (CLIP). The molybdenite ages confirm the rapid evolution of the earliest stages of the Central American Arc, from subduction initiation at 75-73 Ma to arc maturation at $71 \mathrm{Ma}$. A porphyry connection is apparent at Cerro Quema and characterized by highly contorted, banded, and planar quartz-veinlet stockworks and sheeted zones in pyrophylliteand sericite-bearing patchy-textured rock. These are cut by ledges of quartz, alunite, and dickite, which implies overprinting of the advanced argillic lithocap onto the underlying porphyry environment. Hydrothermal telescoping resulted from synmineralization uplift congruent with an actively emerging volcanic arc, which the Re-Os molybdenite dates accurately constrain at $71 \mathrm{Ma}$, presumably as a far-field effect of collision between the leading edge of the CLIP with parts of North and South America.

Keywords: Azuero, Caribean Large Igneous Province, Central American Arc, High-sulfidation, Molybdenite.

\section{RESUMEN}

La edad maastrichtiana temprana, entre los 70,74 y 70,66 millones de años, de la mineralización epitermal de Cu-Au de alta sulfuración en Cerro Quema queda definida mediante dataciones $\mathrm{Re}-\mathrm{Os}$ en molibdenita contenida en vetillas de pirita y enargita. El sistema epitermal evolucionó durante el emplazamiento de un complejo de domos dacíticos en un ambiente geotectónico transicional entre un arco intraoceánico máfico primitivo (Proto Arco Azuero) y un arco de islas más evolucionado (Arco Azuero), durante la construcción inicial de América Central sobre el borde terminal de la provincia magmática caribeña ("Caribbean Large Igneous Province, CLIP'). Las edades en molibdenita confirman la rápida evolución de los estadios tempranos del Arco Centroamericano, desde el inicio de subducción a los 75 - $73 \mathrm{Ma}$, hasta uno de madurez a los $71 \mathrm{Ma}$. Se destaca la relación geológica entre el sistema epitermal de Cerro Quema y un ambiente de tipo pórfido en profundidad, caracterizado este último por un conjunto de vetillas de cuarzo de hábito variable, principalmente irregulares, bandeadas y sinuosas (tipo A), distribuidas en forma de enrejados ("stockworks") y/o como corredores unidireccionales dentro de un pórfido dacítico. Este último desarrolla textura moteada de tipo "patchy", con ensambles de alteración dominados por pirofilita y sericita. Estas zonas de intenso vetilleo están cortadas por cuerpos ("ledges") siliceos con abundante alunita y dickita asociados al desarrollo de una litocapa sobreimpuesta al ambiente de pórfido. Se estima que esta sobreimposición hidrotermal habría resultado como parte del surgimiento del arco volcánico contemporáneo con la mineralización de Cerro Quema, alzamiento que queda constreñido de manera precisa por las edades en molibdenita en los $71 \mathrm{Ma}$. Este alzamiento del arco habría sido, a su vez, gatillado por procesos tectónicos regionales, entre los que se incluye la colisión entre el borde frontal de la CLIP y ciertas regiones continentales de Norte y Sudamérica.

Palabras clave: Azuero, Provincia Magmática Caribeña, Arco Centroamericano, Alta Sulfuración, Molibdenita. 


\section{Introduction}

\subsection{TEGTONIG ASPEGTS}

The geotectonic setting and evolution of the Caribbean realm have long been subjects of much debate and controversy (Malfait and Dinkelman, 1972; Burke, 1988; Pindell et al., 1988, 2005, 2006, 2011; Frisch et al., 1992; Meschede and Frisch, 1998; Kerr et al., 1999, 2003; Kerr and Tarney, 2005; James, 2006; Iturralde-Vinent and Lidiak, 2006; Pindell and Kennan, 2009; Hastie and Kerr, 2010b; Geldmacher et al., 2008). Plate interactions in Cretaceous time, subduction polarity and reversals during construction of the Great Caribbean Arc, the nature and inception of the Caribbean Large Igneous Province (CLIP; also known as Caribbean Plateau) as well as its role in Caribbean tectonics, and the establishment of the Central American land bridge are among the key aspects of this debate (e.g., Pindell et al., 2006). Competing models of the evolution of the CLIP invoke either an allochthonous, Galapagos-related origin for the thick buoyant crust that was later displaced northeastward between the Americas (Malfait and Dinkelman, 1972; Burke, 1988; Duncan and Hargraves, 1984; Kerr et al., 1999; Hoernle et al., 2004; Hastie and Kerr, 2010; Hastie et al., 2010a, 2010b; Whattam et al., 2012; Nerlich et al., 2014), or an autochthonous alternative in which the Caribbean lithosphere formed in an inter-American position, between the North and South American continental blocks (Frisch et al., 1992; Meschede and Frisch, 1998; James, 2006).

With some notable exceptions, most models, particularly those concerned with the geodynamic evolution of the leading, eastern edge of the CLIP during its northeastward migration, pay little attention to its southwestern trailing border and do not constrain the precise timing of the birth of the inter-American land bridge. Various lines of evidence support the hypothesis that this arc segment, also called Central American Arc or South Central American Arc (Buchs et al., 2010, 2011a,2011b, 2016), formed in the latest
Cretaceous on top of the southwestern edge of the CLIP (Lissinna, 2005; Buchs, 2008; Wörner et al., 2009; Wegner et al., 2011; Buchs et al., 2010, 2011a, 2016), with arc initiation timing defined on regional and biochronologic grounds. The reasons for subduction initiation along this trailing part of the CLIP are also poorly established, but traditionally hypothesized to be in response to the diachronous collision between the CLIP and separate North and South American continental blocks (Mitchell, 2003; Kerr and Tarney, 2005; Hastie et al., 2010a, 2010b; Whattam et al., 2012; Boschman et al., 2014; Nerlich et al., 2014; Braz et al., 2018; Cardona et al., 2018) or due to plume-induced spontaneous subduction initiation (Whattam and Stern, 2015; Whattam, 2018).

\subsection{MINERAL DEPOSIT ASPEGTS}

High-sulfidation epithermal deposits are characterized by sulfide-rich mineral assemblages with a high sulfidation state (Einaudi et al., 2003), typically pyrite and enargite, hosted by advanced argillic-altered rocks (Sillitoe, 1983, 1995, 1999; Hedenquist, 1987; White, 1991; Arribas, 1995; Hedenquist et al., 2000). The $\mathrm{Cu}-\mathrm{Au}$ mineralization is genetically related to andesitic-dacitic arc complexes of calc-alkaline composition (Sillitoe, 1993, 1999; Arribas, 1995; Sillitoe and Hedenquist, 2003), and the zones of advanced argillic alteration form lithocaps, which are integral parts of porphyry copper systems (Sillitoe, 1995, 2010). Domes are typical settings for shallow- $(500 \mathrm{~m})$ and intermediate-depth $(<1000$ m) deposits. Vuggy residual quartz and alunite are common in shallower examples, and massive sulfide lodes increase at depth, together with the proportion of pyrophyllite, dickite, and sericite. Tetrahedrite-tennantite plus chalcopyrite characterize intermediate depths, whereas bornite and chalcocite-group minerals hosted by quartz-pyrophyllite and/or sericite alteration occur at the transition to the deeper porphyry environment (Hedenquist et al., 2000; Sillitoe, 1995, 2010). The vuggy residual quartz, together with massive sulfide bodies, mark the principal fluid upflow channels (Sillitoe, 1995, 
1999; Hedenquist et al., 2017), and both alteration and mineralization can be coeval with porphyry copper emplacement at depth (Hedenquist et al., 1998, 2017; Sillitoe, 1995, 2010).

This contribution reports four Re-Os (molybdenite) ages from the porphyry-related Cerro Quema high-sulfidation epithermal $\mathrm{Cu}$-Au deposit in the Azuero Peninsula, Panama (Corral, 2013; Corral et al., 2016; Figure 1). Because a genetic connection between porphyry and high-sulfidation epithermal deposits and subduction-related arc terranes has long been recognized (e.g., Sillitoe and Hedenquist, 2003), these molybdenite ages constrain formation of the epithermal $\mathrm{Cu}-\mathrm{Au}$ mineralization and its underlying porphyry source, and assist with better definition of the timing of inception of arc magmatism and mineralization in the Central American Arc. The precise Re-Os molybdenite ages reported herein are also significant because, with a few modern exceptions (Montes et al., 2012; Ramírez et al., 2016), the majority of geodynamic and tectonomagmatic reconstructions for the region are based on less-reliable $\mathrm{K}-\mathrm{Ar}$ and ${ }^{40} \mathrm{Ar}-{ }^{39} \mathrm{Ar}$ age determinations (Del Giudice and Recchi, 1969; Kesler et al., 1977; Bourgois et al., 1982; Hoernle et al., 2004; Lissinna,
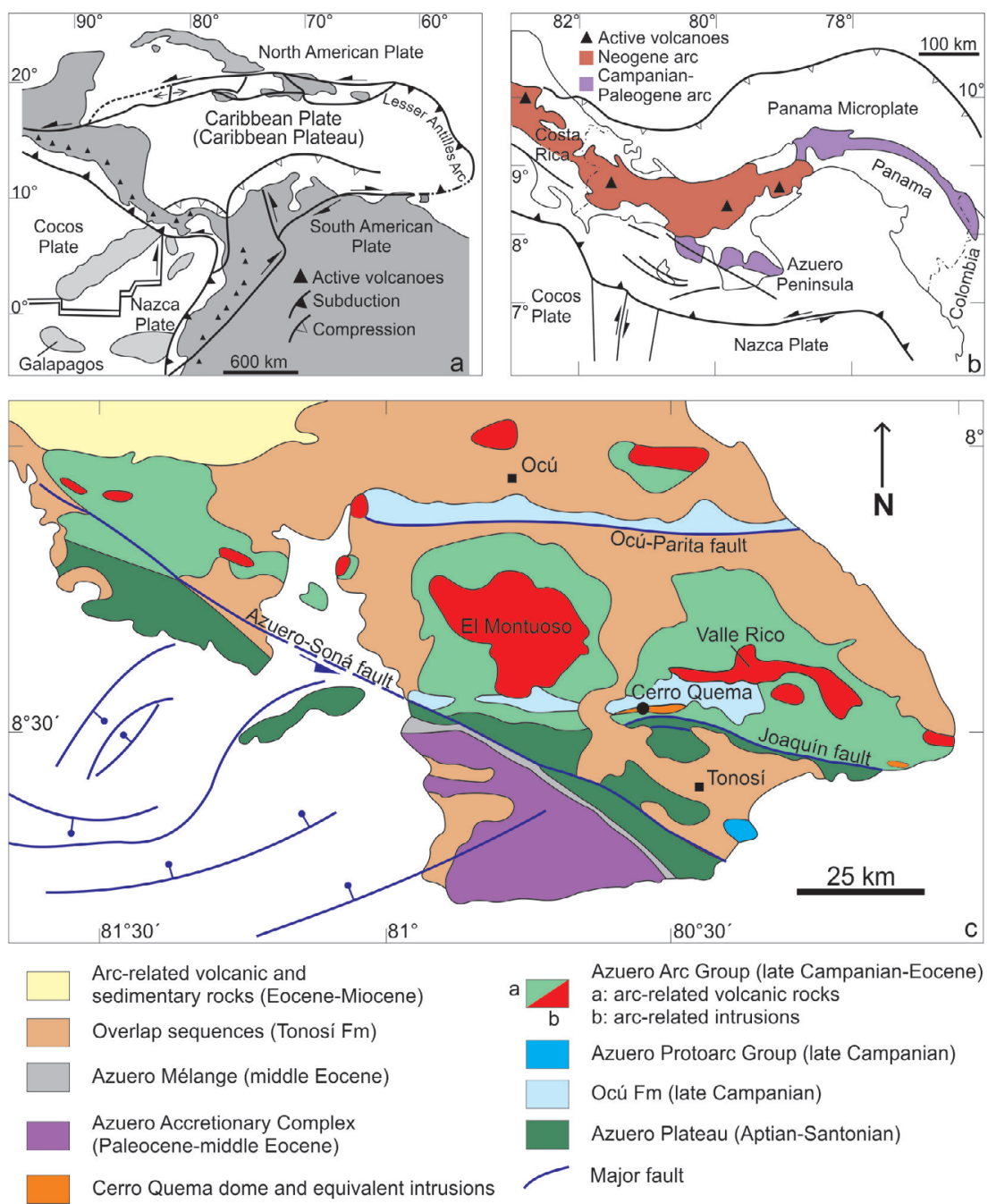

Figure 1 Geologic and geotectonic elements of the Central American region. (a) Sketch map showing the regional geotectonic setting of the Central American land bridge in a Caribbean context (after Wegner et al., 2011). (b) Tectonic setting of the Isthmus of Panama (simplified from Montes et al., 2012). (c) Simplified geological map of the Azuero Peninsula. Mainly after Buchs et al. (2010, 2011a), with additions from Corral et al. (2016). 
2005; Wegner et al., 2011; Corral et al., 2016). Many of these ages are likely compromised by disturbed isotopic systems, including the presence of excess argon and partial to complete resetting and neocrystallization during younger heating events (e.g., Lissinna, 2005, and references therein; Buchs et al., 201 1b; Corral et al., 2016).

\section{Central American Arc and Azuero Peninsula}

The Central American fore-arc region, including the Azuero Peninsula and nearby areas of southern Panama and Costa Rica (Figure 1), comprise an assemblage of in situ CLIP-derived units, volcanoplutonic arcs, and related volcanosedimentary sequences as well as exotic, accreted oceanic blocks (Lissinna, 2005; Denyer et al., 2006; Buchs et al., 2010, 201 la; Corral et al., 2016). Four main lithostratigraphic units are distinguished (Buchs, 2008; Buchs et al., 2010, $2011 \mathrm{a}$ ): the Azuero Plateau, the Ocú Formation, the Azuero Protoarc Group, and the Azuero Arc Group (Figures 1 and 2). These are partially covered by younger sedimentary and volcanosedimentary overlap sequences (e.g., Tonosí Formation; Figures 1 and 2). To the south, rocks of the Azuero Plateau are in tectonic contact with Paleocene to Eocene seamounts, pieces of CLIP, and kilometer-wide mélange zones of the Azuero Accretionary Complex (Buchs et al., 2010, 2011a; Figure 1). The Río Quema Formation (Figure 2), a stratigraphic unit introduced by Corral et al. (2011) for the area of Cerro Quema in the central Azuero Peninsula, comprises detrital calcareous strata interbedded with Azuero Arc Group components.

The Azuero Plateau contains massive, columnar, and pillowed lava flows of basaltic composition. The interbedded radiolarian chert defines a Coniacian to early Santonian ( 89-85 Ma) age for the sequence (Kolarsky et al., 1995; Buchs et al., 2010). The volcanic rocks and associated gabbro intrusions have the geochemical features of low-K oceanic tholeiitic plateau basalts and are interpreted to be uplifted parts of the CLIP (Lissinna,
2005; Buchs, 2008; Wörner et al., 2009; Buchs et al., 2010, $2011 \mathrm{a}$; Corral et al., 2011, 2016; Wegner et al., 2011; Wattham and Stern, 2015). The radiolarian age assignment is broadly consistent with modern ${ }^{40} \mathrm{Ar}-{ }^{39} \mathrm{Ar}$ geochronological data that confirm basaltic magmatism between $\sim 93$ and 83 Ma (Lissinna, 2005), in general agreement with the timing of principal CLIP plateau formation (Kerr et al., 1999, 2003; Hoernle et al., 2004). The Azuero Plateau basalts have a geochemical signature similar to other oceanic plateau sequences from the Caribbean and so have been considered to represent the southwestern trailing edge of the GLIP and the autochthonous basement over which the Central American Arc was initiated in the late Campanian (Buchs et al., 2010, $2011 \mathrm{a}$ ).The Ocú

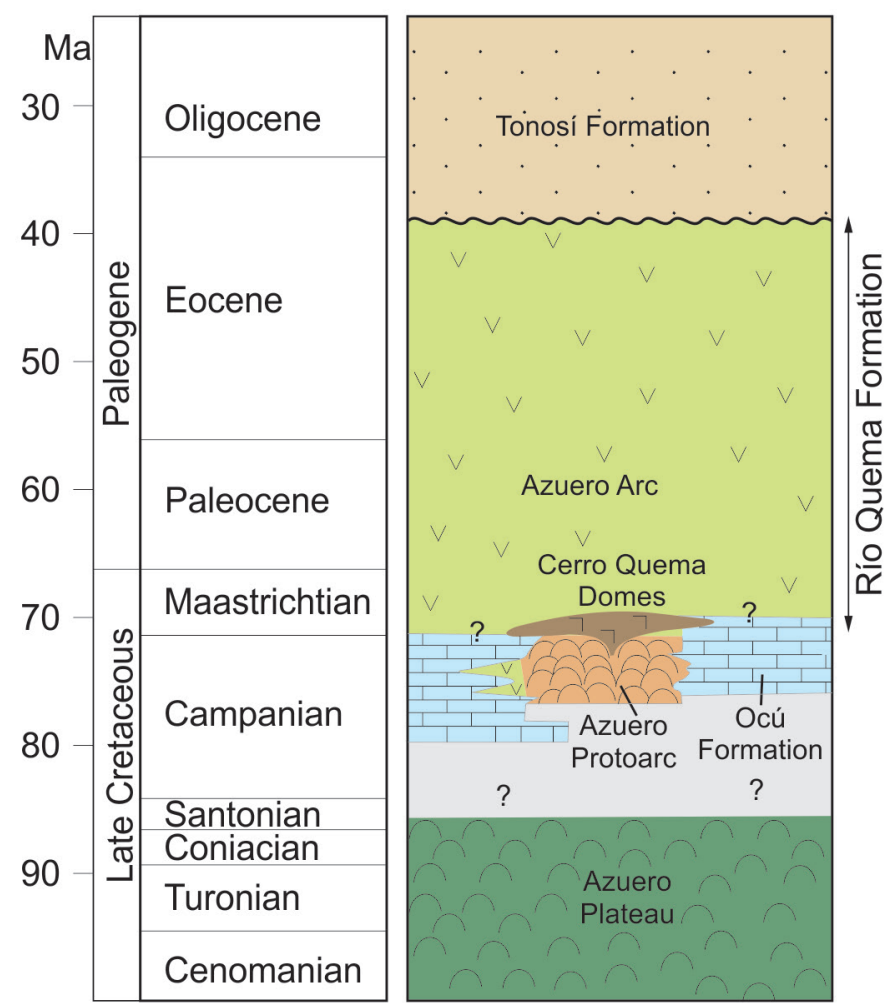

Figure 2 Simplified stratigraphic column for the Azuero Peninsula. Elements from Buchs et al. (2010, 2011a) and Corral et al. (2016 and references therein). Note the close relationships between the composite Cerro Quema dacite dome at the transition from Azuero Protoarc primitive lava flows and more differentiated Azuero Arc volcanic rocks, with intervening Ocú Formation carbonate rocks. The transition from Protoarc to Arc assemblages at the Campanian-Maastrichtian boundary reflects major regional geodynamic changes. 
Formation (Figures 1 and 2) is a foraminifera-bearing sequence of pelagic and hemipelagic limestone interbedded with volcanosedimentary rocks and basaltic flows of the Azuero Protoarc and basal parts of the Azuero Arc groups (Del Giudice and Recchi, 1969; Buchs et al., 2010, 2011a; Corral et al., 2013). The calcareous rocks vary from clean micritic through detrital to tuffaceous limestone, the last rich in quartz, feldspar, amphibole, and pumice fragments suggestive of an intermediate-composition volcanic source (Buchs et al., 2010, 2011 a; Corral et al., 2013). Local tuffaceous layers together with conglomeratic strata imply a shallow depositional environment and the presence of nearby subaerial conditions (Buchs et al., 2010, $2011 \mathrm{a})$. The formation is interpreted to rest upon the basalts of the Azuero Plateau and its age to be late Campanian ( 75-73 Ma; Buchs et al., 2010), although formaminiferal assemblages from similar rocks in the vicinity of Cerro Quema (Río Quema Formation) expand this age to include the early Maastrichtian (Corral et al., 2013). The Ocú Formation accumulated on top of the Azuero Plateau during the earliest stages of the Central American Arc and correlates with equivalent strata in foreand back-arc regions of Costa Rica as well as with pelagic carbonate rocks that rest upon the CLIP in the Caribbean Basin (Bowland and Rosencrantz, 1988; Bowland, 1993). The calcareous rocks of the Río Quema Formation (Corral et al., 2016), as well as similar sequences elsewhere in the region, are considered to represent facies variations of the Ocú Formation (Buchs et al., 2010, 2011 a).

Exposures of Azuero Protoarc Group rocks are mainly present in islands offshore the peninsula and by equivalent units in Costa Rica (Buchs et al., 2011a). The scattered outcrops assigned to the Group in the Azuero Peninsula consist of pillowed mafic lava flows interbedded with Ocú Formation limestone together with abundant crosscutting mafic dikes (Buchs et al., 2010, 2011 a). Pyroxene-bearing, porphyritic basaltic lava flows and dikes are common and possess petrochemical features transitional between CLIP oceanic basement and early, primitive arc rocks (Wörner et al., 2009; Wegner et al., 2011; Buchs et al., 2010, 2011 a; Whattam and Stern, 2015). In the Azuero Peninsula, the MORB and within-plate tholeiitic chemistry of these rocks suggest that the Protoarc Group represents a late Campanian to early Maastrichtian primitive island arc sequence at the onset of magmatism in the Central American Arc (Buchs et al., 2010, 2011 a; Corral et al., 2013, 2016; Whattam and Stern, 2015).

Rocks of the Azuero Arc Group are well exposed in the Azuero Peninsula (Figure 1), where the Group is dominantly composed of basaltic to intermediate volcanic rocks interbedded with calcareous and tuffaceous sedimentary rocks (Kolarsky et al., 1995; Lissinna, 2005; Wörner et al., 2009; Wegner et al., 2011; Buchs et al., 2010, 2011 a; Corral et al., 2013, 2016). The volcanic rocks are typically porphyritic in texture, range from pyroxene-bearing basalt to quartz- and amphibole-bearing dacite, and occur as massive lava flows and flow-dome complexes. Lower parts of the Group possess petrochemical features characteristic of intraoceanic volcanic arc settings, with MORB, island arc tholeiitic, and within-plate tholeiitic signatures (Buchs et al., 2010, 201 la; Corral et al., 2013). Large variations in composition exist in the upper parts of the sequence, implying that the Group is the product of several different events during the Late Cretaceous to middle Eocene (Lissinna, 2005; Buchs et al., 2011 a). Stratigraphic, paleontological, and geochronological data constrain the age of the lower part of the Azuero Arc Group to the late Campanian to Maastrichtian (Buchs et al., 2010, 2011 a; Corral, 2013; Corral et al., 2013, 2016). In the Cerro Quema area, these rocks are intruded by the dome-related, amphibole-bearing dacitic stocks of the Río Quema Formation that yield ${ }^{40} \mathrm{Ar}-{ }^{39} \mathrm{Ar}$ (amphibole) ages of 71-70 Ma (early Maastrichtian; Wegner et al., 2011; Corral et al., 2016; Figures 1 and 2), thereby confirming the Group's age assignment. Younger ages of $\sim 68$ to $65 \mathrm{Ma}$ obtained for the Cerro Quema dacite dome (Corral et al., 2016) as well as ages of 65 to 52 Ma for Azuero Arc basaltic rocks (Lissinna, 2005, and references therein) could have 
been affected by thermal events generated by $\mathrm{El}$ Montuoso and Valle Rico batholith emplacement. These arc-related intrusions, of granodioritic to dioritic composition, occur along an east-west corridor to the north and northwest of the Cerro Quema area (Figure 1) and possess U-Pb zircon ages of 68 to $66 \mathrm{Ma}$ (El Montuoso; Montes et al., 2012; Ramírez et al., 2016) and 49 Ma (Valle Rico; Montes et al., 2012).

In summary, broadly coeval rocks of the Azuero Protoarc Group, lower parts of the Azuero Arc Group, and regional equivalents (Azuero-Soná Arc; Wörner et al., 2009; Wegner et al., 2011) are characterized by primitive suprasubduction arc signatures that support earliest evolution of the Central American Arc between the late Campanian and early Maastrichtian ( 75-70 Ma; Buchs, 2008; Buchs et al., 2010, 201 la; Corral et al., 2013, 2016), whereas more differentiated, calc-alkaline, emergent arc volcanism is recorded higher in Azuero Arc stratigraphy (Buchs et al., 201 la; Corral et al., 2013).

\section{Synopsis of Cerro Quema Geology}

Mineralization in the Cerro Quema area occurs as several centers of which La Pava, Cerro Quema, and Cerro Quemita are the most important (Figure 3). A combined total (measured, indicated, and inferred) oxide resource of $24.6 \mathrm{Mt}$ at 0.71 $\mathrm{g} / \mathrm{t} \mathrm{Au}$ and $0.04 \% \mathrm{Cu}$ plus $11.4 \mathrm{Mt}$ at $0.41 \mathrm{~g} / \mathrm{t}$ $\mathrm{Au}$ and $0.31 \% \mathrm{Cu}$ of sulfidic material has been estimated (Sutcliffe et al., 2014), with a large proportion of it $(26.8 \mathrm{Mt})$ at La Pava. Each center is funnel shaped and comprises near-surface supergene oxide ore underlain by sulfide protore, all occurring in association with advanced argillic alteration (Yang et al., 1997; Corral, 2013; Corral et al., 2010, 2016, 2017, 2018; Figure 3). All the centers are hosted by a west-trending quartz-, feldspar-, and hornblende-bearing dacite dome complex with a strike extent of $\sim 25 \mathrm{~km}$ that, together with other dacite bodies farther east, forms a $\sim 70 \mathrm{~km}$ long corridor along the Azuero Peninsula (Corral et al.,
2016). The dacite dome complex was emplaced in a volcaniclastic sedimentary sequence of the Azuero Arc Group (Figure 2), which in the Cerro Quema area also contains limestone and andesitic lava flows of the Río Quema Formation (Corral et al., 2011, 2016; Figure 2). The dome complex comprises intrusive porphyritic and flow-banded phases of coarse-grained dacite, together with fine-grained crystal- and lithic-bearing tuffaceous rocks and blocky and brecciated hyaloclastite apron deposits. The regional Joaquín fault system marks the structural contact with Azuero Plateau units just south of Cerro Quema (Buchs, 2008; Buchs et al., $2011 \mathrm{a}$; Corral et al., 2013, 2016; Figure 1). The alteration and mineralization at Cerro Quema were previously interpreted to have taken place under subaerial conditions in genetic association with a blind, subvolcanic porphyry intrusion emplaced during the Eocene Valle Rico magmatic episode ( $55-49 \mathrm{Ma})$, some 15 to $20 \mathrm{My}$ after dacite dome emplacement (Corral et al., 2016, 2017).

A typical concentric alteration zoning pattern is apparent in all the centers, with central vuggy residual quartz and alunite followed outward by zones of kaolinite and dickite and, more externally, illite and chlorite. At La Pava, alteration and mineralization are associated with a large, multiphase, polylithic, clast- or matrix-supported hydrothermal breccia body (e.g., Corral et al., 2016, 2017; Figure 4), which cuts the dacite dome complex. The central silicic parts of the breccia contain both vuggy residual quartz and introduced quartz in the form of fine-grained silicification (Figures 3 and 4), with voids partly filled and lined by one or more of alunite, barite, rutile, pyrite, and enargite, plus localized chalcopyrite. Alunite and natroalunite are present as hydrothermal breccia cement, together with barite, dickite, and aluminum phosphate-sulfate minerals (Corral et al., 2016). Pyrite, enargite, and tennantite are typical phases in the breccia cement, in which chalcopyrite is also a conspicuous component.

The central silicic core at La Pava is surrounded by a zone of quartz, dickite, and kaolinite alteration that gradually changes with depth to a 
mixed assemblage in which pyrophyllite dominates along with sericite and illite in various proportions (Figure 3). Ledges with quartz, alunite, and dickite overprint a zone of patchy-textured rock characterized by irregular, interspersed patches of pyrophyllite, plus lesser sericite and illite, and finegrained quartz similar to assemblages described from upper parts of porphyry systems elsewhere (Gustafson et al., 2004; Sillitoe et al., 2013). Moderate to intense stockworks of irregular, sinuous, and contorted vein-like forms of fine-grained quartz, but also containing semicontinuous banded quartz veinlets and granular quartz veinlets of A-type ( $c f$. Gustafson and Hunt, 1975), are present (Figure 4). These textures suggest proximity to underlying potential porphyry copper mineralization ( $c f$. Gustafson et al., 2004; Sillitoe, 2010). The quartz stockworks contain principally pyrite, but chalcopyrite also occurs locally.

Deep drilling ( $\sim 900 \mathrm{~m})$ at other centers in the Cerro Quema area has revealed similar features to those at La Pava, with pyrophyllite-bearing assemblages rich in pyrite and enargite plus lesser covellite and hypogene chalcocite as well as

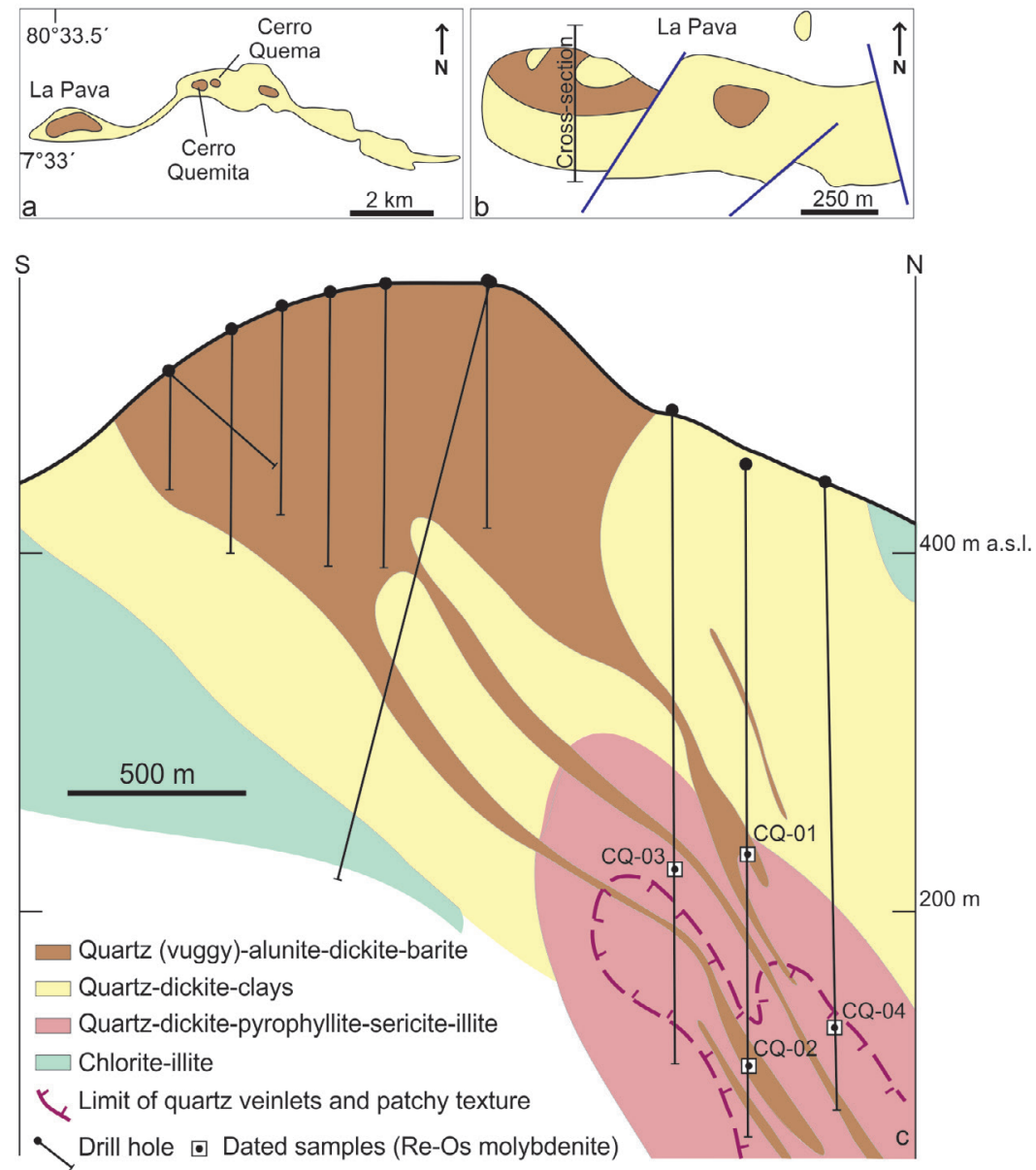

Figure 3 Elements of Cerro Quema geology. (a) Extent of the advanced argillic lithocap with location of three principal centers at La Pava, Cerro Quema, and Cerro Quemita (Yang et al., 1997). (b) Close-up of La Pava alteration zone (Corral et al., 2016) with location of cross-section shown in (c) (Yang et al., 1997; Sutcliffe et al., 2014). (c) Schematic cross-section through La Pava showing the funnel-like geometry of the advanced argillic alteration, with quartz-alunite preserved in the upper part (after Yang et al., 1997) and pyrophyllitesericite-illite becoming widespread at depth. Note the contour of the patchy-textured rock and associated quartz-veinlet stockworks and sheeted zones defining the apical part of the porphyry copper environment (see Figure 4 for details of textures and assemblages) and the transgressive advanced argillic alteration ledges. The overall geometry suggests tilting to the south. The locations of dated samples CQ-01 to CQ-04 are also shown. 

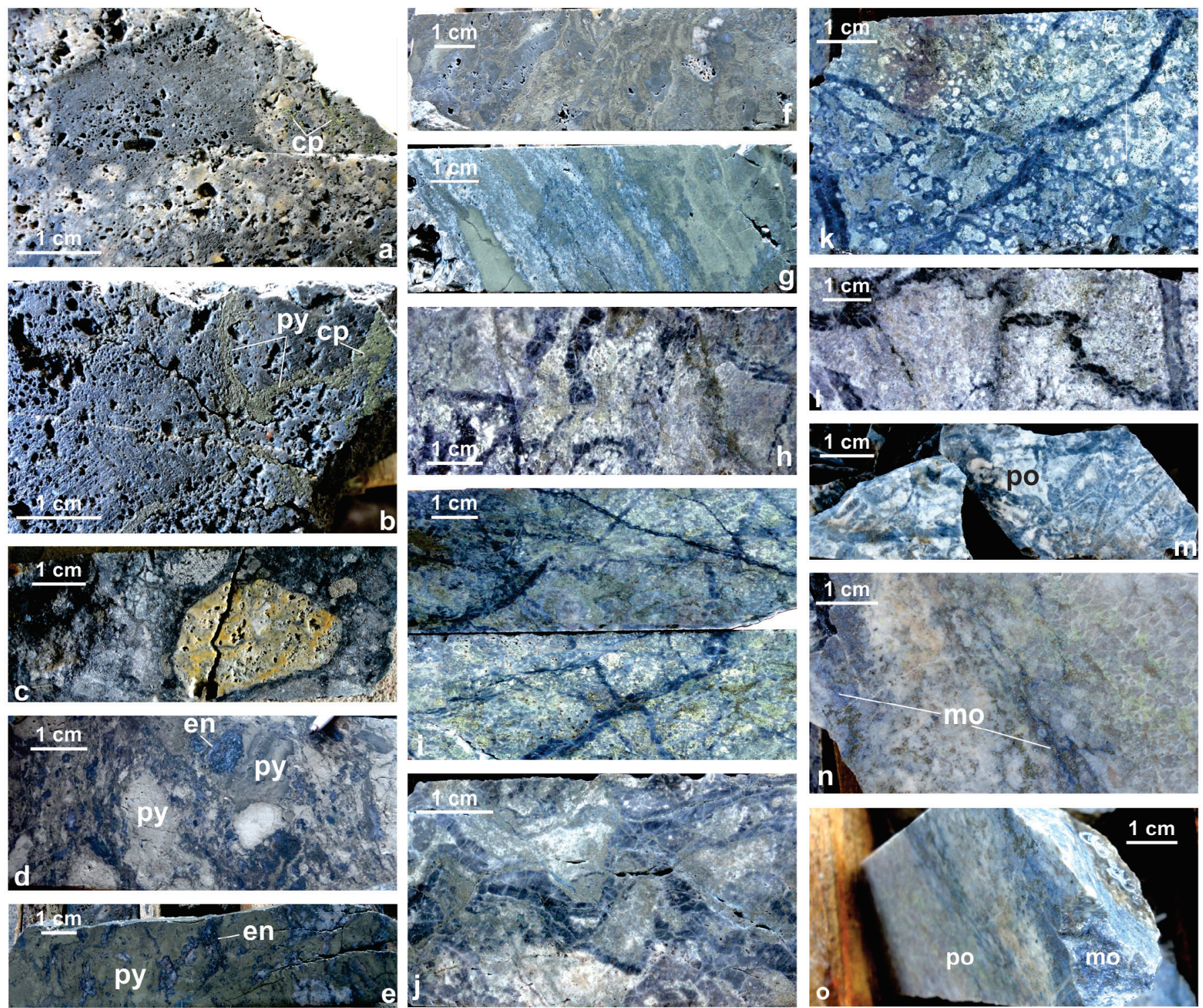

Figure 4 Selected photographs of La Pava. (a,b) Vuggy residual quartz rock with pyrite and chalcopyrite mineralization. (c-f) Various examples of the hydrothermal breccia body that hosts the bulk of the mineralization, including clast of vuggy residual quartz, sulfidecemented zones, and massive sulfide zones following bedding planes. $(\mathrm{h}-\mathrm{m})$ Aspects of the quartz-veinlet stockwork zones highlighting the contorted and banded nature of early veinlet events crosscut by younger, more planar veinlets. The pyrophyllite-dominated patchy texture $(m)$ involves intense quartz veining. $(n, 0)$ Samples of molybdenite in pyrophyllite-sericite-illite-altered rock, with molybdenite occurring as irregular seams and fractures in ledges with quartz-alunite, pyrite, and enargite. Abbreviations: cp: chalcopyrite; en: enargite; mo: molybdenite; py: pyrite; po: pyrophyllite.

anastomosing stockworks of quartz and anhydrite veinlets, some carrying chalcopyrite and molybdenite (Sutcliffe et al., 2014). B-type quartz veinlets are described together with inter- to late-mineral quartz-feldspar porphyry dikes and associated phreatomagmatic breccia bodies, all of which are interpreted as porphyry indicators (Sutcliffe et al., 2014). Overprinting of deeper, pyrophyllite-stable, chalcopyrite-molybdenite mineralization by shallower advanced argillic assemblages and associated high-sulfidation pyrite-enargite mineralization has been observed in most holes (Sutcliffe et al., 2014). Shallow, funnel-shaped upflow zones at Cerro Quema contain central quartz-pyrophyllite alteration surrounded by assemblages in which quartz and pyrophyllite are accompanied by kaolinite and interlayered clays (Yang et al., 1997). The prograde downward 
advance of the pyrophyllite front, the transgressive nature of the vuggy residual quartz and quartz-alunite ledges over pyrophyllite-bearing, patchy-textured rock and porphyry-type quartz-veinlet stockworks, and the presence of important chalcopyrite and tennantite as breccia cement and vuggy quartz infill are together taken to indicate that the Cerro Quema system is preserved at the transition between the basal parts of a lithocap and the top of the porphyry environment. Molybdenite is common in the deeper parts of the downward transgressive ledges at La Pava (Figure 3), confirming that the zone represents the upflow from a causative porphyry intrusion at depth ( $c f$. Sillitoe, 1995, 1999, 2010). Contouring of alteration zones and quartz-veinlet stockworks suggest an apparent $60^{\circ}$ southerly tilt of the coupled porphyry-epithermal system at La Pava (Figure 3), although this observation requires further confirmation.

\section{Re-Os Molybdenite Geochronology}

Dated samples CQ-01, CQ-02, CQ-03, and CQ-04 were collected from various hydrothermal breccia dikes and ledges, ranging from meter to decimeter widths and cutting fine-grained tuffaceous and porphyritic dacite at La Pava (Figure 3). In accord with the descriptions above, the breccia bodies display intense silicification and advanced argillic alteration, the latter comprising vuggy residual quartz, alunite, dickite, kaolinite, and barite. Petrographic work shows that the millimetric vugs are filled by barite, pyrite, and enargite whereas remnants of tabular plagioclase phenocrysts are replaced by well-crystallized kaolinite, rosettes of dickite, and peripheral alunite. In the transgressive ledges, the rock was transformed to fine-grained, sugary aggregates of quartz, rutile, dickite, and alunite, with hairline cracks filled by well-crystallized dickite, alunite, prismatic barite, pyrite, and enargite. Sulfide minerals occur as disseminations that nucleate in former plagioclase and ferromagnesian sites as well as along irregular hairline fractures. The pyrite is fine grained and microgranular, and forms aggregates with enargite and microneedles of molybdenite in a paragenetic sequence from pyrite through molybdenite to enargite. Where pyrite and chalcopyrite occur together, contact relationships indicate that the pyrite formed first, with local chalcopyrite containing inclusions or preserving cores of pyrite. A similar sulfide paragenetic sequence has been established at the Cerro Quema center (Corral et al., 2016).

\subsection{ANALYTICAL METHODS AND RESULTS}

Molybdenite separates from samples CQ-01, CQ-02, CQ-03, and CQ-04 were obtained by means of standard metal-free crushing, followed by gravity and magnetic concentration (Selby and Creaser, 2004; Kellog and Vega, 1995). The ${ }^{187}$ Re and ${ }^{187} \mathrm{Os}$ concentrations in molybdenite were determined by isotope dilution mass spectrometry using Carius-tube, solvent extraction, anion chromatography and negative thermal ionization mass spectrometry techniques. A mixed double spike containing known amounts of isotopically enriched ${ }^{185} \mathrm{Re},{ }^{190} \mathrm{Os}$, and ${ }^{188} \mathrm{Os}$ was used (Markey et al., 2007). The isotopic analyses were made using a ThermoScientific Triton mass spectrometer by Faraday collector. Total procedural blanks for Re and $\mathrm{Os}$ are $<3$ picograms and 2 picograms, respectively. These procedural blanks are insignificant in comparison to the Re and Os concentrations in molybdenite. A Chinese molybdenite powder (HLP-5; Markey et al., 1998) is used routinely as control sample. The uncertainty for all ages is quoted at $2 \sigma$ level and includes all known analytical uncertainties, including a $\sim 0.31 \%$ uncertainty in the decay constant of ${ }^{187} \mathrm{Re}$.

Samples CQ-01, CQ-02, and CQ-03 yielded model ages between $70.74 \pm 0.29$ and $70.66 \pm 0.29$ Ma, whereas sample CQ-04 reported a younger age of 68.72 $\pm 0.29 \mathrm{Ma}$ (Figure 3; Table 1). However, this last sample contains significant common Os (1226 pg; Table 1), unusually high for molybdenite and possibly implying the presence of some sulfide impurity, rendering the age less reliable. 
Table 1. Re-Os isotopic and age data. Cerro Quema, Panama

\begin{tabular}{|c|c|c|c|c|c|c|c|c|c|}
\hline Sample & Re ppm & $\pm 2 \sigma$ & 187Re ppm & $\pm 2 \sigma$ & 1870s ppb & $\pm 2 \sigma$ & $\begin{array}{c}\text { Common Os } \\
\text { pg }\end{array}$ & Model Age (Ma) & $\pm 2 \sigma(\mathrm{Ma})$ \\
\hline CQ-01 & 1027 & 3 & 645 & 2 & 760.2 & 0.5 & $<5$ & 70.66 & 0.29 \\
\hline CQ-02 & 3649 & 9 & 2294 & 6 & 2703 & 2 & $<5$ & 70.70 & 0.29 \\
\hline CQ-03 & 660.6 & 1.7 & 415.2 & 1.1 & 489.7 & 0.3 & 37 & 70.74 & 0.29 \\
\hline CQ-04 & 6016 & 16 & 3782 & 10 & 4332 & 5 & 1226 & 68.72 & 0.29 \\
\hline
\end{tabular}

\section{Discussion}

\subsection{TEGTONOMAGMATIC SETTING}

The 70.74 to $70.66 \mathrm{Ma}$ age range for the three reliable molybdenite samples from La Pava clearly constrain the earliest Maastrichtian age for the high-sulfidation alteration and mineralization at $\mathrm{La}$ Pava and for the entire Cerro Quema deposit. This age range is in agreement with the ${ }^{40} \mathrm{Ar}-{ }^{39} \mathrm{Ar}$ dates of $\sim 71$ Ma for amphibole-bearing dacitic rocks from the Cerro Quema area (Wegner et al., 2011; Corral et al., 2016) and confirms the volcanic dome-related setting for the epithermal $\mathrm{Cu}-\mathrm{Au}$ mineralization: a classic environment for high-sulfidation epithermal deposits in magmatic arcs (Sillitoe, 1993, 1999; Arribas, 1995; Sillitoe and Hedenquist, 2003).

Although originally considered to be exclusively constructed of CLIP material (e.g., Hoernle et al., 2004), many oceanic terranes in Panama and Costa Rica have, more recently, been shown to contain mature suprasubduction igneous associations that represent various stages of arc construction atop the CLIP (Denyer et al., 2006; Buchs, 2008; Wörner et al., 2009; Buchs et al., 2010, 2019; Wegner et al., 2011; Whattam et al., 2012). The 93 to $83 \mathrm{Ma}$ oceanic rocks, upon which this early stage of the arc evolved, represent the southernmost trailing edge of the CLIP, which is interpreted to form the bulk of the Caribbean Plate (e.g., Kerr et al., 2003; Figures 1 and 5). Early arc construction, involving protoarc mafic lavas that mark the transition from intraplate oceanic to arc magmatism, was followed by generation of typical arc-like lavas and related intrusions (Lissinna, 2005; Wörner et al., 2009; Buchs et al., 2010; Wegner et al., 2011). In this context, Azuero Protoarc Group rocks represent the earliest stages of intraoceanic arc construction in the late Campanian, with subduction initiation estimated at between $\sim 75$ and 73 $\mathrm{Ma}$, to be followed by the more formal calc-alkaline Azuero Arc (Buchs, 2008; Buchs et al., 2010, 2011 a; Corral et al., 2010; Figure 5).

The exact timing of establishment of the Azuero Arc is not well constrained in the literature, with the onset of island arc construction being broadly estimated as somewhere between the Maastrichtian and earliest Paleocene ( 71-66 Ma) in parts of Panama and Costa Rica (Buchs, 2008; Buchs et al., 2010, 2011 a) or, more generally in the region, during the Campanian (84-71 Ma; Pindell and Kennan, 2009). The molybdenite ages reported herein are the first to more accurately constrain the timing of the transition from primitive intraoceanic arc magmatism (Azuero Protoarc) to the more formal calc-alkaline Azuero Arc, which must have been active in the earliest Maastrichtian, at $\sim 71 \mathrm{Ma}$, to generate the dacite dome complex and associated mineralization at La Pava and elsewhere at Cerro Quema (Figures 5 and 6). In this sense, the molybdenite ages help to confirm establishment of the Central American Arc (or South Central American island arc) by the earliest Maastrichtian, with initiation of subduction of the Farallon plate beneath the CLIP-dominated Caribbean plate at $\sim 75-73 \mathrm{Ma}$ (cf. Buchs et al., 2010, 2011 a; Figure 5b). This 2 to $4 \mathrm{My}$ period is shorter than the average 5 to 8 My estimate modeled for transitional processes between subduction initiation and arc maturation (Stern and Gerya, 2017, and references therein), but compares favorably with present-day examples as short as $2 \mathrm{My}$ (e.g., Patriat et al., 2019)

The reasons for subduction initiation along the Central American Arc are still controversial. However, most tectonic models favor east-dipping 
subduction at the trailing southwestern edge of the CLIP being triggered by arrival of the leading, eastern edge of the CLIP at the subduction zone beneath the Great Antillean Arc, with consequent jamming of the subduction system (Kerr et al., 1999; Pindell et al., 2005; Pindell and Kennan, 2009; Hastie et al., 2010a, 2010b; Whattam et al., 2012). Collisions with parts of the Americas (Mitchell, 2003; Hastie et al., 2010a, 2010b; Hastie and Kerr, 2010; Whattam et al., 2012; Boschman et al., 2014; Nerlich et al., 2014; Braz et al., 2018;
Cardona et al., 2018) are also possibilities (Figure 5c) that could have imposed major tectonic changes in the Central American Arc that, in turn, caused arc maturation. A far-field effect of such collisions, whereby a significant component of inter- and intraplate compression, uplift, and exhumation resulted from a marked increase in coupling of the Caribbean and North and South American plates at 7 1-70 Ma (Kerr and Tarney, 2005; Kennan and Pindell, 2009; Buchs et al., 2010), is also plausible (Figure 5c).
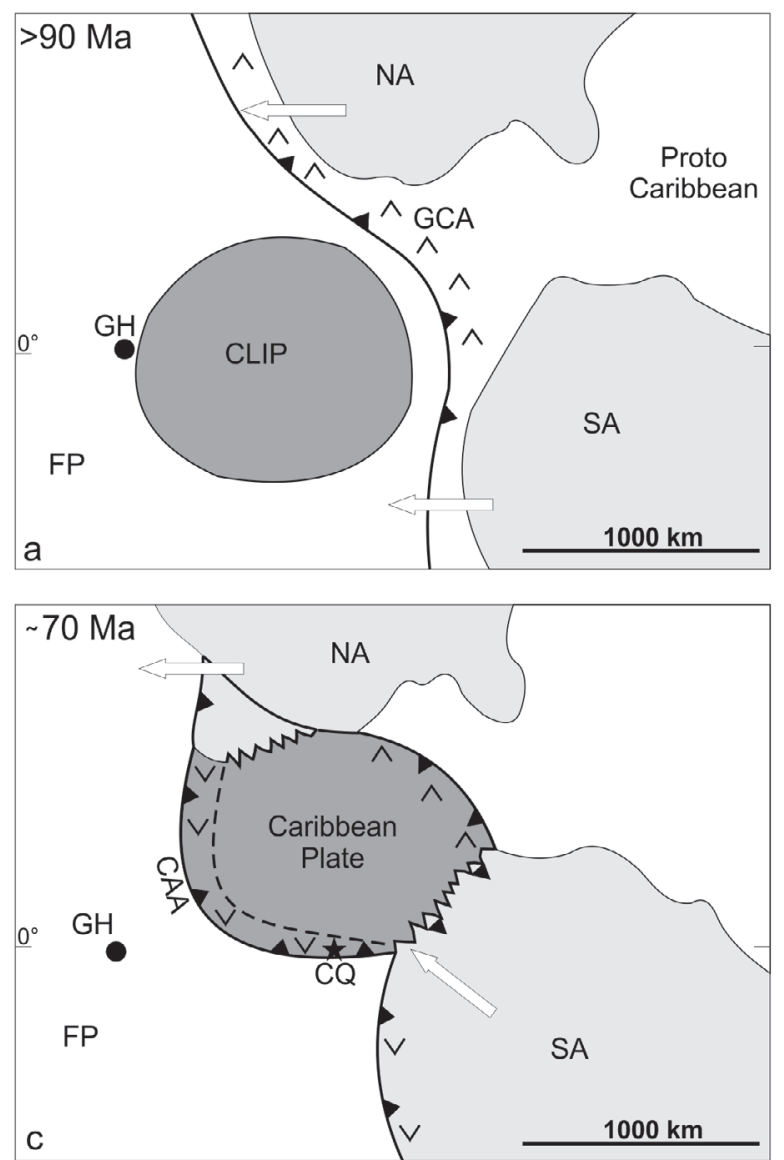

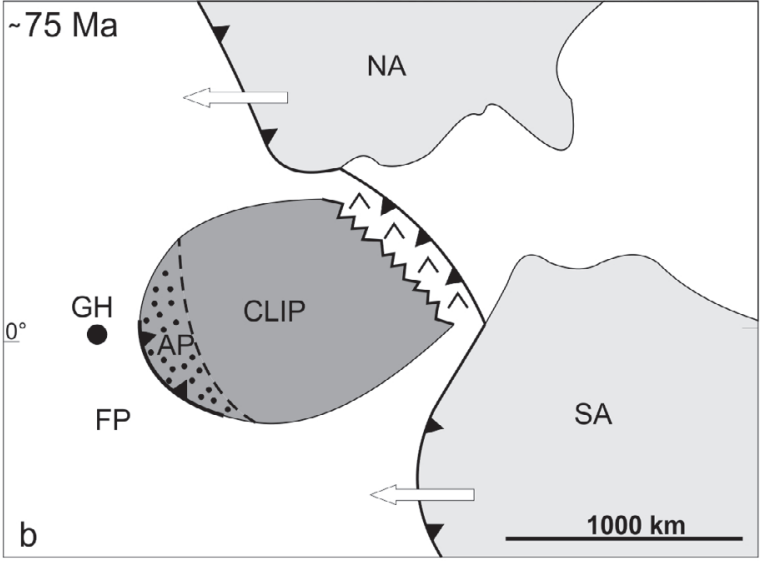

Relative motion of continental masses

MWM Collision zone

Azuero Protoarc and Arc

$\because \because \quad$ Azuero Plateau (AP)

Caribbean Large Igneous Province (CLIP)

Great Caribbean Arc

Figure 5 Ilustrations showing the interaction between the Caribbean Large Igneous Province (CLIP), proto-Caribbean oceanic crust, and the large continental blocks of North and South America. (a) Displays the setting of the Great Caribbean Arc before arrival of the Galapagos-sourced CLIP. (b) Shows the Caribbean plate during collision of the leading edge of the CLIP with the Great Caribbean Arc and subduction polarity reversal. Note inception of a new subduction zone at the Azuero Plateau on the trailing edge of the CLIP, which forms the primitive Central American intraoceanic arc and associated tholeiitic volcanism. (c) Displays the collision of the CLIP with parts of North and South America and the more evolved development of the Central American Arc. The porphyry-related epithermal mineralization at Cerro Quema (shown by a star) was emplaced in this tectonomagmatic environment. Geologic and tectonomagmatic elements borrowed from multiple sources including Kerr et al. (1999), Mitchell (2003), Kerr and Tarney (2005), Kennan and Pindell (2009), Buchs et al. (2010, 2011, 2018), Hastie et al. (2010a, 2010b), Hastie and Kerr (2010), Wright and Wyld (2011), and Whattam et al. (2012). Abbreviations: AP: Azuero Plateau; CAA: Central American Arc; CQ: Cerro Quema; FP: Farallon Plate; GCA: Great Caribbean Arc; GH: Galapagos Hotspot; NA: North American Plate; SA: South American Plate. 


\subsection{IMPLICATIONS FOR MINERALIZATION}

The 70.74 to $70.66 \mathrm{Ma}$ (early Maastrichtian) molybdenite age range contradicts the $\sim 55$ to $49 \mathrm{Ma}$ (early Eocene) age assignment by Corral et al. (2016) for the high-sulfidation $\mathrm{Cu}-\mathrm{Au}$ mineralization at Cerro Quema as well as its genetic association with a blind porphyry stock of the Eocene Valle Rico suite. The porphyry copper environment is indeed present in depth at La Pava as evidenced by the highly contorted and banded granular quartz-veinlet stockworks and sheeted zones together with classic porphyry-type A quartz veinlets in pyrophyllite-bearing alteration (Figures 3 and 4), which together imply the presence of a deeper causative porphyry stock (Figures 6a, b). Similar porphyry copper indicators have also been described for the other mineralized centers at Cerro Quema (Sutcliffe et al., 2014). Given the distance of $\sim 3 \mathrm{~km}$ between La Pava and the other centers, it may be speculated that La Pava and Cerro Quema-Cerro Quemita were sourced by separate, although simultaneously evolving, porphyry copper stocks.

The relative abundance of chalcopyrite together with enargite in the principal metal-bearing stages at Cerro Quema (Corral et al., 2016, 2017) make this deposit an unusual example of the high-sulfidation epithermal class (cf., Einaudi $e t$ al., 2003; Figure 6c). In general, in high-sulfidation systems, chalcopyrite and tennantite-tetrahedrite tend to increase with depth as the porphyry environment is approached (Arribas, 1995; Hedenquist et al., 2000; Sillitoe, 2010). The occurrence of multiple stages of mineralization involving various proportions of pyrite, chalcopyrite, enargite, and tennantite, plus local bornite, in which chalcopyrite is paragenetically both early and late with respect to enargite (Corral et al., 2016, 2017), may reflect the peculiar, confined pathway followed by the mineralizing fluid during its evolution from intermediate- to high-sulfidation conditions ( $c f$. Einaudi et al., 2003; Figure 6c). The rapid transition is herein ascribed to synmineralization telescoping of the system as a result of tectonic uplift and arc emergence (Figure 6b). Tectonic surface uplift and erosion during the lifespan of the epithermal-porphyry couple is speculated to have been in part controlled by structural adjustments in the Joaquín structural corridor (Figure 1). The apparent southerly tilting of the system could also have taken place at this time. Although a broad Paleocene timing for the transpressive activity along this fault corridor has been inferred previously (Corral et al., 2013, 2016), the mutually crosscutting relationships between the Joaquín structures and the 71-Ma Cerro Quema dacite dome complex would rather suggest a simultaneous evolution. Inversion along the Joaquín fault system could have been the product of far-field strain accommodation associated with collision or accretion of bathymetric objects along southern Central America (Denyer et al., 2006; Wegner et al., 2011; Montes et al., 2012; Rodriguez-Parra et al., 2016), some broadly contemporaneous with arc evolution in the Azuero Peninsula, which resulted in demonstrable rapid $(\sim 1 \mathrm{~km} / \mathrm{My})$, kilometer-scale surface uplift (Andjić et al., 2018). Arc emergence induced by kilometric uplift would have, in turn, favored deposition of shallow-water calcareous sediments and the volcaniclastic turbidites that characterize the volcanosedimentary sequence of the central Azuero region (Buchs et al., 2011a; Corral et al., 2016; Figure 2). Volcanic-dome emergence and its alteration and mineralization under subaerial conditions at Cerro Quema are also evidenced by the fluid inclusion and isotopic signatures of the hydrothermal fluids, in which dilution of magmatic fluid by meteoric water was a prerequisite, without participation of seawater (e.g., Corral et al., 2017).

Regionally, the high-sulfidation epithermal cluster at Cerro Quema, as well as other epithermal prospects associated with dacitic domes and Azuero Arc Group rocks elsewhere in the Azuero Peninsula (Medina Molero et al., 2014; Corral et al., 2016), are likely to be part of the same metallogenic event. In contrast, epithermal mineralization hosted by younger intrusions (e.g., El Montuoso batholith; Corral et al., 2016) must belong to separate metallogenic events linked to arc maturation. 

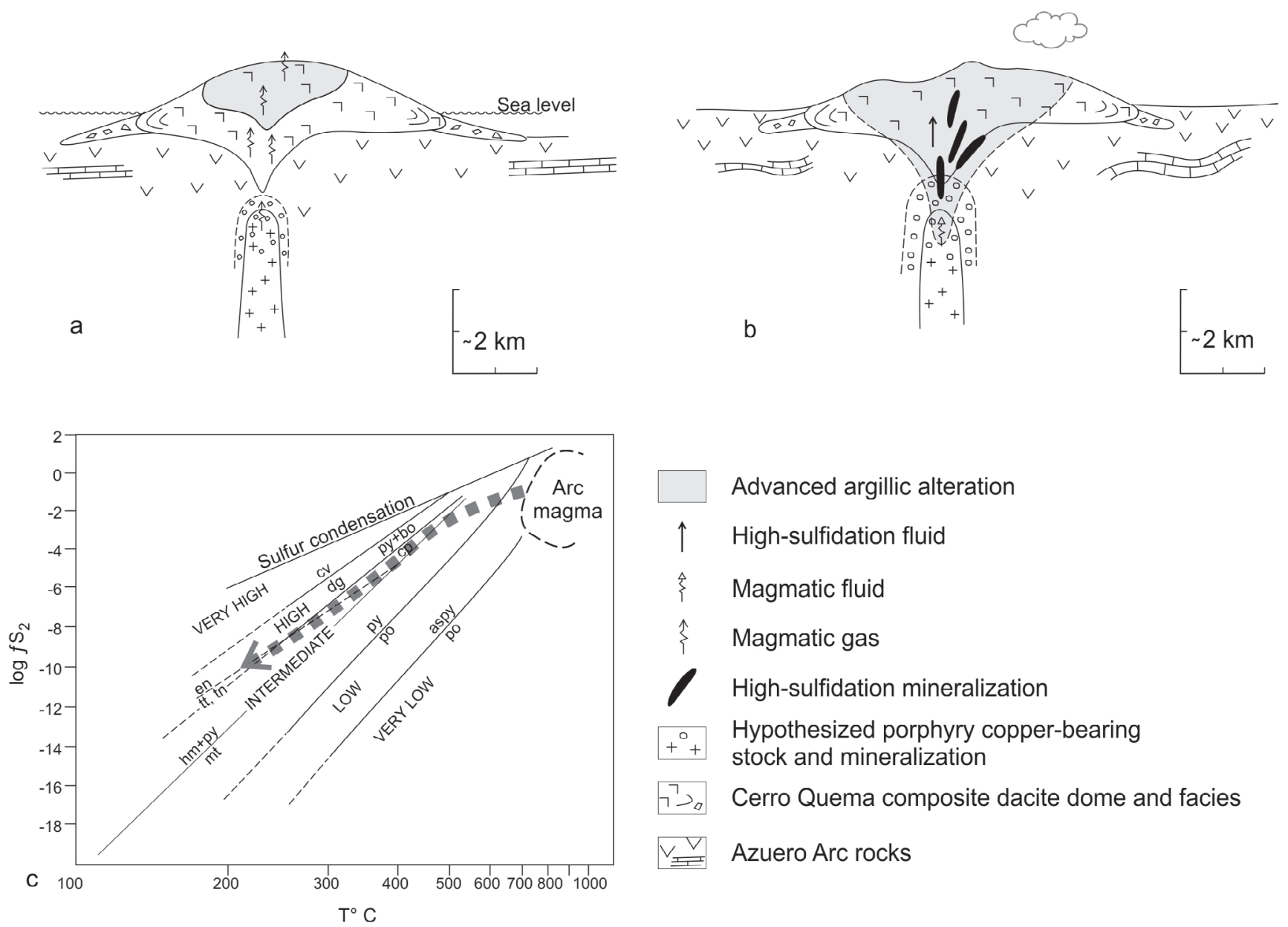

Advanced argillic alteration

High-sulfidation fluid

Magmatic fluid

Magmatic gas

High-sulfidation mineralization

Hypothesized porphyry copper-bearing

stock and mineralization

Cerro Quema composite dacite dome and facies

Azuero Arc rocks

Figure 6 Schematic model for the emplacement of the Cerro Quema dacite dome complex and associated porphyry-epithermal mineralization. (a) Emplacement of Cerro Quema dacite dome in part under subaquatic conditions to form the associated hyaloclastite apron deposits (Corral et al., 2013, 2016). A degassing porphyry stock at depth, decoupled from the shallow epithermal environment, contributed to the formation of initial lithocap assemblages. (b) Progressive development of the porphyry-epithermal couple broadly coincident with regional arc emergence and consequent uplift of the system. The apical part of the porphyry source reaches the epithermal environment, with the bulk of the epithermal mineralization taking place under subaerial conditions (Corral et al., 2017). Tectonic deformation is inferred, and the postulated tilting of the porphyry-epithermal system could have taken place at this time. (c) Inferred pathway of the epithermal fluid from the porphyry environment, showing its confinement to the boundary between chalcopyrite and enargite stability and its evolution from intermediate- toward high-sulfidation conditions. Diagram simplified from Einaudi et al. (2003). Mineral abbreviations: aspy: arsenopyrite; bo: bornite; cv: covellite; cp: chalcopyrite; dg: digenite; en: enargite; hm: hematite; mt: magnetite; po: pyrrhotite; py: pyrite; tn: tennantite; tt: tetrahedrite.

\subsection{METALLOGENIC IMPLICATIONS}

The precise new age data for La Pava clarify the genetic relationship between the Cerro Quema mineralization and the primitive magmatism that represents the transition from intraoceanic to island arc settings during early stages of the Central American Arc (or South Central American Arc) as well as confirming that porphyry-related high-sulfidation epithermal deposits can form in such environments. A similar conclusion was reached for the Pueblo Viejo district in the Dominican Republic, where contemporaneous porphyry and high-sulfidation alteration-mineralization and tholeiitic volcanism characterized the change from subduction initiation to formal subduction during inception of Great Arc of the Caribbean island arc (Torró et al., 2017a, 2017b). However, although 
the arc-related mafic lavas of the Azuero Protoarc Group were in part erupted simultaneously with the more-differentiated, calc-alkaline products of the Azuero Arc Group (Buchs, 2008; Buchs et al., 2010, 2011a), the volcanic dome-related alteration and mineralization at Cerro Quema evolved under subaerial conditions in association with the younger, more differentiated suite and not in a submarine mafic environment as envisioned, for example, at Pueblo Viejo (Kesler et al., 2005; Kirk et al., 2014; Nelson et al., 2015).

\section{Conclusions}

The 70.74 to $70.66 \mathrm{Ma}$ age range for molybdenite accompanying high-sulfidation epithermal mineralization at Cerro Quema confirms rapid evolution of the inter-American land bridge from subduction initiation at $\sim 75-73$ Ma through early, primitive intraoceanic mafic to more evolved island arc magmatism at $\sim 71 \mathrm{Ma}$ to form the Central American Arc. The dynamism of the geotectonic setting is inferred to have been primarily a response to far-field effects of regional collision of leading parts of the CLIP with continental North and South America, although accretion of buoyant bathymetric objects on the down-going Farallon plate could also have been important for arc maturation.

Under these active tectonomagmatic conditions, and early during magmatic arc inception, a coupled porphyry-epithermal system was established at Cerro Quema in genetic association with a composite, dacitic dome complex while primitive, mafic volcanism was still regionally active. Subaerial conditions were rapidly attained due to regional volcanic arc emergence, and resulted in variable degrees of hydrothermal telescoping at the various mineralized centers at Cerro Quema. The new radiometric dates reported herein are the first to directly and precisely document the age of the high-sulfidation mineralization and lithocap formation. The stockworks and sheeted zones of highly contorted, banded, and planar quartz veinlets in pyrophyllite-stable alteration at La Pava and elsewhere at Cerro Quema are expressions of the apical parts of the porphyry environment and suggest at least two causative porphyry copper stocks are present at depth. These should be drill tested, particularly in proximity to the more reactive limestone horizons of the Ocú Formation and related calcareous sequences that are common in the area and likely to occur subsurface.

\section{Acknowledgments}

We thank Dick Sillitoe, David Buchs, and Carl Nelson for reviews and comments, Paula Cornejo for petrographic work, Héctor Poblete for figure preparation, and Mike Druecker and Alain Bureau for assistance during field work and geologic discussions. An early e-mail exchange with Isaac Corral is also appreciated. Hans Smit approved publication of molybdenite ages on behalf of Orla Mining Ltd. This article was motivated by an invitation from Antoni Camprubí to contribute to this special volume on mineral deposits of Latin America and the Caribbean.

\section{References}

Andjić, G., Baumgartner, P.O., BaumgartnerMora, C., 2018, Rapid vertical motions and formation of volcanic arc gaps: Plateau collision recorded in the forearc geological evolution (Costa Rica margin): Basin Research,30(5), 863 - 894. https://doi. org/10.1111/bre.12284

Arribas, A., 1995, Characteristics of highsulfidation epithermal deposits, and their relation to magmatic fluid: Mineralogical Association of Canada Short Course, 23, 419-454.

Boschman, L.M., van Hinsbergen, D.J.J., Torsvik, T.H., Spakman, W., Pindell, J.L., 2014, Kinematic reconstruction of the Caribbean region since the Early Jurassic: Earth-Science 
Reviews, 138, 102-136. https://doi. org/10.1016/j.earscirev.2014.08.007

Bourgois, J., Azema, J., Tournon, J., Bellon, H., Calle, B., Parra, E., Toussaint, J.F., Glacon, G., Feinberg, H., Dewever, P., Origlia, I., 1982, Ages and structures of the basic and ultrabasic complexes of the Pacific coast between 3-Degrees-N and 12-Degrees-N (Colombia, Panama and Costa-Rica): Bulletin de la Société Géologique de France, 24(3), 545-554. https://doi.org/10.2113/ gssgfbull.s7-xxiv.3.545

Bowland, C.L., 1993, Depositional history of the western Colombian basin, Caribbean Sea, revealed by seismic stratigraphy: Geological Society of America Bulletin, 105(10), 1321$1345 . \quad$ https://doi.org/10.1130/00167606 (1993)1 05<1321:dhotwc $>2.3$. co;2

Bowland, C.L., and Rosencrantz, E., 1988, Upper crustal structure of the western Colombian basin, Caribbean Sea: Geological Society of America Bulletin, 100(4), 534$546 . \quad$ https://doi.org/10.1130/00167606 (1988)1 $00<0534:$ ucsotw $>2.3$. co;2

Braz, C., Seton, M., Flament, N., Müller, R.D., 2018, Geodynamic reconstruction of an accreted Cretaceous back-arc basin in the Northern Andes: Journal of Geodynamics 121, 115-132. https://doi.org/10.1016/j. jog.2018.09.008

Burke, K., 1988, Tectonic evolution of the Caribbean: Annual Review of Earth and Planetary Sciences, 16(1), 201-230. https:// doi.org/10.1146/annurev.earth.16.1.201

Buchs, D.M., 2008, Late Cretaceous to Eocene geology of the South Central American forearc area (southern Costa Rica and western Panama): initiation and evolution of an intra-oceanic convergent margin: Lausanne, Switzerland, Université de Lausanne, Unpublished Ph.D. thesis, 238 p.

Buchs, D.M., Arculus, R.J., Baumgartner, P.O., Baumgartner-Mora, C., Ulianov, A., 2010,
Late Cretaceous arc development on the SW margin of the Caribbean plate: Insights from the Golfito, Costa Rica, and Azuero, Panama, complexes: Geochemistry, Geophysics, Geosystems, 11(7), Q07S24. https://doi. org/10.1029/2009gc002901

Buchs, D.M., Baumgartner, P.O., BaumgartnerMora, G., Flores, K., Bandini, A.N., 2011a, Upper Cretaceous to Miocene tectonostratigraphy of the Azuero area (Panama) and the discontinuous accretion and subduction erosion along the Middle American margin: Tectonophysics, 512(14), 31-46. https://doi.org/10.1016/j. tecto.2011.09.010

Buchs, D.M., Arculus, R.J., Baumgartner, P.O., Ulianov, A., 2011b, Oceanic intraplate volcanoes exposed: Example from seamounts accreted in Panama: Geology, 39(4), 335338. https://doi.org/10.1130/g31703.1

Buchs, D.M., Hoernle, K., Hauff, F., Baumgartner, P.O., 2016, Evidence from accreted seamounts for a depleted component in the early Galapagos plume: Geology, 44(5), 383386. https://doi.org/10.1130/g37618.1

Buchs, D.M., Kerr, A.C., Brims, J.C., ZapataVillada, J.P., Correa-Restrepo, T., Rodríguez, G., 2018, Evidence for subaerial development of the Caribbean oceanic plateau in the Late Cretaceous and palaeo-environmental implications: Earth and Planetary Science Letters, 499, 62-73. https://doi. org/10.1016/j.epsl.2018.07.020

Buchs, D.M., Cooms, H., Irving, D., Wang, J., Koppers, A., Miranda, R., Coronado, M., Tapia, A., Pitchford, S., 2019, Volcanic shutdown of the Panama Canal area following breakup of the Farallon plate: Lithos, 334-335, 190-204. https://doi. org/10.1016/j.lithos.2019.02.016

Cardona, A., León, S., Jaramillo, J.S., Montese, C., Valencia, V., Vanegas, J., Bustamanteg, C., Echeverri, S., 2018, The Paleogene arcs of the northern Andes of Colombia and Panama: Insights on plate kinematic 
implications from new and existing geochemical, geochronological and isotopic data: Tectonophysics 749, 88-103. https:// doi.org/10.1016/j.tecto.2018.10.032

Corral, I., 2013, Geology and metallogeny of the Cerro Quema Au-Cu deposit (Azuero Peninsula, Panama): Unpublished Ph.D. thesis, Barcelona, Spain, Universitat Autònoma de Barcelona, 211 p.

Corral, I., Griera, A., Gómez-Gras, D., Corbella, M., Cardellach, E., 2010, Geochemical evolution of the Panamanian CretaceousPaleogene volcanic arc: Insights from the Azuero Peninsula, SW Panama: Geogaceta, 49, 79-82.

Corral, I., Griera, A., Gómez-Gras, D., Corbella, M., Canals, À., Pineda-Falconett, M., Cardellach, E., 2011, Geology of the Cerro Quema Au-Cu deposit (Azuero Peninsula, Panama): Geologica Acta, 9, 481-498. https://doi.org/10.1344/105.000001742

Corral, I., Gómez-Gras, D., Griera, A., Corbella, M., Cardellach, E., 2013, Sedimentation and volcanism in the Panamanian Cretaceous intraoceanic arc and fore-arc: New insights from the Azuero Peninsula (SW Panama): Bulletin de la Société Géologique de France, 184(1-2), 35-45. https://doi.org/10.2113/ gssgfbull.184.1-2.35

Corral, I., Cardellach, E., Corbella, M., Canals, A., Gómez-Gras, D., Griera, A., Cosca, M.A., 2016, Cerro Quema (Azuero Peninsula, Panama): Geology, alteration, mineralization, and geochronology of a volcanic domehosted high-sulfidation $\mathrm{Au}-\mathrm{Cu}$ deposit: Economic Geology, $111(2), 287-310$. https:// doi.org/10.2113/econgeo.111.2.287

Corral, I., Cardellach, E., Corbella, M., Canals, A., Griera, A., Gómez-Gras, D., Johnson, C.A., 2017, Origin and evolution of mineralizing fluids and exploration of the Cerro Quema $\mathrm{Au}-\mathrm{Cu}$ deposit (Azuero Peninsula, Panama) from a fluid inclusion and stable isotope perspective: Ore Geology Reviews, 80, 947-960. https://doi.org/10.1016/j. oregeorev.2016.09.008
Corral, I., Corbella, M., Gómez-Gras, D., Griera, A., 2018, Trace-metal content of the Cerro Quema Au-Cu deposit (Azuero Peninsula, Panama): Implications for exploration: Boletín de la Sociedad Geológica Mexicana, 70(2), 549-565. https://doi.org/10.18268/ bsgm2018v70n2a14

Del Giudice, D., Recchi, G., 1969, Geología del área del Proyecto Minero de Azuero. Informe técnico preparado para el gobierno de la República de Panamá por las Naciones Unidas, actuando y participando como agencia ejecutora: Gobierno de la República de Panamá, 48 p.

Denyer, P., Baumgartner, P.O., Gazel, E., 2006, Characterization and tectonic implications of Mesozoic-Cenozoic oceanic assemblages of Costa Rica and Western Panama: Geologica Acta, 4, 219-235. https://doi. org/10.1344/105.000000367

Duncan, R.A., and Hargraves, R.B., 1984, Plate tectonic evolution of the Caribbean region in the mantle reference frame: Geological Society of America Memoir 162, 89-121. https://doi.org/10.1130/MEM162-p81

Einaudi, M.T., Hedenquist, J.W., Inan, E.E., 2003, Sulfidation state of fluids in active and extinct hydrothermal systems: Transitions from porphyry to epithermal environments: Society of Economic Geologists Special Publication 10, 285-313.

Frisch, W., Meschede, M., Sick, M., 1992, Origin of the Central American ophiolites: Evidence from paleomagnetic results: Geological Society of America Bulletin, 104(10), 1301-1314. https://doi. org/10.1130/0016-7606(1992)104<1301:ootcao $>2.3 . c 0 ; 2$

Geldmacher, J., Hoernle, K., van Den Bogaard, P., Hauff, F., Klügel, A., 2008, Age and geochemistry of the Central American forearc basement (DSDP Leg 67 and 84): Insights into Mesozoic arc volcanism and seamount accretion on the fringe of the Caribbean LIP: Journal of Petrology, 49(10), 1781-1815. https://doi.org/10.1093/ petrology/egn046 
Gustafson, L. B., and Hunt, J. P., 1975, The porphyry copper deposit at El Salvador, Chile: Economic Geology, 70(5), 857-912. https:// doi.org/10.2113/gsecongeo.70.5.857

Gustfason, L.B., Vidal, C.E., Pinto, R., Noble, D.C., 2004, Porphyry-epithermal transition, Cajamarca region, northern Peru: Society of Economic Geologists Special Publication 11, 279-298.

Hastie, A.R., and Kerr, A.C., 2010, Mantle plume or slab window?: Physical and geochemical constraints on the origin of the Caribbean oceanic plateau: Earth-Science Reviews, 98(3-4), 283-293. https://doi.org/10.1016/j. earscirev.2009.11.001

Hastie, A.R., Ramsook, R., Mitchell, S.F., Kerr, A.C., Millar, I.L., Mark, D.F., 2010a, Geochemistry of compositionally distinct Late Cretaceous back-arc basin lavas: Implications for the tectonomagmatic evolution of the Caribbean plate: The Journal of Geology, 118(6), 655-676. https:/ / doi.org/10.1086/656353

Hastie, A.R., Kerr, A.C., McDonald, I., Mitchell, S.F., Pearce, J.A., Millar, I.L., Barfod, D., Mark, D.F., 2010b, Geochronology, geochemistry and petrogenesis of rhyodacite lavas in eastern Jamaica: A new adakite subgroup analogous to early Archaean continental crust?: Chemical Geology, 276(34), 344-359. https://doi.org/10.1016/j. chemgeo.2010.07.002

Hedenquist, J.W., 1987, Volcanic-related hydrothermal systems in the Circum-Pacific basin and their potential for mineralisation: Mining Geology (Kozan Chishitsu), 37, 347-364.

Hedenquist, J.W., Arribas, A., Reynolds, T.J., 1998, Evolution of an intrusion-centered hydrothermal system: Far SoutheastLepanto porphyry and epithermal $\mathrm{Cu}-\mathrm{Au}$ deposits, Philippines: Economic Geology, 93(4), 373-404. https://doi.org/10.2113/ gsecongeo.93.4.373
Hedenquist, J. W., Arribas, A., Gonzalez-Urien, E., 2000, Exploration for epithermal gold deposits: Reviews in Economic Geology, 13, 245-277.

Hedenquist, J.W., Arribas, A., Aoki, M., 2017, Zonation of sulfate and sulfide minerals and isotopic composition in the Far Southeast porphyry and Lepanto epithermal $\mathrm{Cu}-\mathrm{Au}$ deposits, Philippines: Resource Geology, 67(2), 174-196. https://doi.org/10.1111/ rge. 12127

Hoernle, K., Hauff, F., van Den Bogaard, P., 2004, 70 m.y. history (139-69 Ma) for the Caribbean large igneous province: Geology, 32(8), 697-700. https://doi.org/10.1130/ g20574.1

Iturralde-Vinent, M.A., and Lidiak, E.G., 2006. Caribbean tectonic, magmatic, metamorphic and stratigraphic events: Geologica Acta, 4, $1-5$.

James, K.H., 2006, Arguments for and against the Pacific origin of the Caribbean plate: discussion, finding for an inter-American origin: Geologica Acta, 4, 279-302.

Kellog, J.N., and Vega, V., 1995, Tectonic development of Panama, Costa Rica, and the Colombian Andes: Constraints from global positioning system geodetic studies and gravity: Geological Society of America Special Paper 295, 75-90. https://doi. org/10.1130/spe295-p75

Kennan, L., Pindell, J.L., and 2009, Dextral shear, terrane accretion and basin formation in the Northern Andes: Best explained by interaction with a Pacific-derived Caribbean Plate: Geological Society, London, Special Publications, 328(1), 487-531. https://doi. org/10.1144/sp328.20

Kerr, A.C., Iturralde-Vinent, M.A., Saunders, A.D., Babbs, T.L., Tarney, J., 1999, A new plate tectonic model of the Caribbean: implications from a geochemical reconnaissance of Cuban Mesozoic volcanic rocks: Geological Society of America 
Bulletin, 111(11), 1581-1599. https://doi. org/10.1130/0016-7606(1999)111<1581:an ptmo $>2.3 . c 0 ; 2$

Kerr, A.C., White, R.V., Thompson, P.M.E., Tarney, J., Saunders, A.D., 2003, No oceanic plateau - no Caribbean plate? The seminal role of an oceanic plateau in Caribbean plate evolution: American Association of Petroleum Geologists Memoir 79, 126-268. https://doi.org/10.1306/M79877C6

Kerr, A.C., and Tarney,J., 2005, Tectonic evolution of the Caribbean and northwestern South America: The case for accretion of two Late Cretaceous oceanic plateaus: Geology, 33(4), 269-272. https://doi.org/10.1130/g21 109.1

Kesler, S.E., Sutter,J.F., Issigonis, M.J., Jones, L.M., Walker, R.L., 1977, Evolution of porphyry copper mineralization in an oceanic island arc: Panama: Economic Geology, 72(6), 1142-1153. https://doi.org/10.2113/ gsecongeo.72.6.1142

Kesler, S.E., Campbell, I.H., Smith, C.N., Hall, C.H., Allen, C.M., 2005, Age of the Pueblo Viejo gold-silver deposit and its significance to models for high-sulfidation epithermal mineralization: Economic Geology, 100(2), 253-272. http://dx.doi.org/10.2113/ gsecongeo.100.2.253

Kirk, J.D., Ruiz, J., Kesler, S.E., Simon, A., Muntean, J.L., 2014, Re-Os age of the Pueblo Viejo epithermal deposit, Dominican Republic: Economic Geology, 109(2), 503-512. https://doi.org/10.2113/ econgeo.109.2.503

Kolarsky, R.A., Mann, P., Monechi, S., MeyerhoffHull, D., Pessagno, E.A., 1995, Stratigraphic development of southwestern Panama as determined from integration of marine seismic data and onshore geology: Geological Society of America Special Paper 295, 159200. https://doi.org/10.1130/spe295-p159

Lissinna, B., 2005, A profile through the Central American land bridge in western Panama: 115 Ma interplay between the Galápagos hotspot and the Central American subduction zone: Kiel, Germany, GhristianAlberchts-Universität zu Kiel, Unpublished Ph.D. thesis, 102 p.

Malfait, B.T., and Dinkelman, M.G., 1972, Circum-Caribbean tectonic and igneous activity and the evolution of the Caribbean plate: Geological Society of America Bulletin, 83(2), 251-272. https://doi. org/10.1130/0016-7606(1972)83[251:ctaiaa ]2.0.co;2

Markey, R.J., Stein, H.J., Morgan, J.W., 1998, Highly precise Re-Os dating for molybdenite using alkaline fusion and NTIMS: Talanta, 45(5), 935-946. https://doi.org/10.1016/ s0039-9140(97)00198-7

Markey, R., Stein, H.J., Hannah, J.L., Zimmerman, A., Selby, D., Creaser, R.A., 2007, Standardizing Re-Os geochronology: A new molybdenite reference material (Henderson, USA) and the stoichiometry of Os salts: Chemical Geology, 244(1-2), 74-87. https:// doi.org/10.1016/j.chemgeo.2007.06.002

Medina Molero, M., Corral, I., Cardellach, E., 2014, Estudio mineralógico del depósito de Au de Pitaloza (Península de Azuero, Panamá): Sociedad Española de Mineralogía, Macla, 19, 2 p.

Meschede, M., and Frisch, W., 1998, A platetectonic model for the Mesozoic and Early Cenozoic history of the Caribbean plate: Tectonophysics, 296(3-4), 269-291. https:// doi.org/10.1016/s0040-1951(98)00157-7

Mitchell, S. F., 2003, Sedimentology and tectonic evolution of the Cretaceous rocks of central Jamaica: Relationships to the plate tectonic evolution of the Caribbean: AAPG Memoir 79, 605- 623.

Montes, G., Bayona, G., Cardona, A., Buchs, D.M., Silva, C.A., Morón, S., Hoyos, N., Ramírez, D.A., Jaramillo, C.A., Valencia, V., 2012, Arc-continent collision and orocline formation: Closing of the Central American seaway: Journal of Geophysical Research, 117, B04105. https://doi. org/10.1029/2011jb008959 
Nelson, G.E., Stein, H.J., Dominguez, H., Carrasco, C., Barrie, T., Torró, L., Proenza, J., 2015, Re-Os dating of molybdenite from the Pueblo Viejo Au-Ag-Cu and Douvray $\mathrm{Cu}-\mathrm{Au}$ districts, Hispaniola: Economic Geology, 110(4), 1101-1110. https://doi. org/10.2113/econgeo.110.4.1101

Nerlich, R., Clark, S.R., Bunge, H-P., 2014, Reconstructing the link between the Galapagos hotspot and the Caribbean plateau: GeoResJ, 1-2, 1-7. https://doi. org/10.1016/j.grj.2014.02.001

Patriat, M., Falloon, T., Danyushevsky, L., Collot, J., Jeand, M.M., Hoernle, K., Hauff, F., Maas, R., Woodhead, J.D., Feigh, S.T., 2019, Subduction initiation terranes exposed at the front of a 2 Ma volcanically-active subduction zone: Earth and Planetary Science Letter, 508, 30-40. https://doi. org/10.1016/j.epsl.2018.12.011

Pindell, J.L., and Kennan, L., 2009, Tectonic evolution of the Gulf of Mexico, Caribbean and northern South America in the mantle reference frame: an update: Geological Society, London, Special Publications, 328(1), 1-55. https://doi.org/10.1144/ sp328.1

Pindell, J.L., Cande, C., Pitman III, W.C., Rowley, D.B., Dewey, J.F., Labrecque, J., Haxby, W., 1988, A plate-kinematic framework for models of Caribbean evolution: Tectonophysics, 155(1-4), 121-138. https:// doi.org/10.1016/0040-1951(88)90262-4

Pindell, J.L., Kennan, L., Maresch, W.V., Stanek, K-P., Draper, G., Higgs, R., 2005, Platekinematics and crustal dynamics of circumCaribbean arc-continent interactions: Tectonic controls on basin development in proto-Caribbean margins: Geological Society of America Special Paper, 394, 7-52. https://doi.org/10.1130/0-8137-2394-9.7

Pindell, J.L., Kennan, L., Maresch, W.V., Stanek, K-P., and Draper, G., 2006, Foundations of Gulf of Mexico and Caribbean evolution: eight controversies resolved:
Geologica Acta, 4, 303-341. https://doi. org/10.1344/105.000000371

Pindell, J.L., Maresch, W.V., Martens, U., Stanek, K., 2011, The Greater Antillean Arc: Early Cretaceous origin and proposed relationship to Central American subduction mélanges: implications for models of Caribbean evolution: International Geology Review, 54(2), 131-143. https://doi.org/10.1080/00 206814.2010 .510008

Ramírez, D.A., Foster, D.A., Min, K., Montes, C., Cardona, A., Sadove, G., 2016, Exhumation of the Panama basement complex and basins: Implications for the closure of the Central American seaway: Geochemistry, Geophysics, Geosystems, 17(5), 1758-1777. https://doi.org/10.1002/2016gc006289

Rodriguez-Parra, L.A., Gaitani, C., Montes, C., Bayona, G., Rapalini, A., 2016, Arc-seamount collision: driver for vertical-axis rotations in Azuero, Panama: Studia Geophysica et Geodaetica, 61(2), 199-218. https://doi. org/10.1007/s1 1200-016-1173-1

Selby, D., and Creaser, R.A., 2004, Macroscale NTIMS and microscale LA-MG-ICP-MS Re-Os isotopic analysis of molybdenite: Testing spatial restrictions for reliable Re-Os age determinations, and implication for the decoupling of Re and Os within molybdenite: Geochimica et Cosmochimica Acta, 68(19), 3897-3908. https://doi.org/10.1016/j. gсa.2004.03.022

Sillitoe, R.H., 1983, Enargite-bearing massive sulfide deposits high in porphyry copper systems: Economic Geology, 78(2), 348-352. https://doi.org/10.2113/ gsecongeo.78.2.348

Sillitoe, R.H., 1993, Giant and bonanza gold deposits in the epithermal environment: Assessment of potential genetic factors: Society of Economic Geologists Special Publication 2, 125-156.

Sillitoe, R.H., 1995, Exploration of porphyry copper lithocaps: Pacrim Congress 1995, Auckland, New Zealand, 1995, Proceedings: 
Melbourne Australasian Institute of Mining and Metallurgy, 527-532.

Sillitoe, R.H., 1999, Styles of high-sulphidation gold, silver and copper mineralisation in the porphyry and epithermal environments: Pacrim'99 Congress, Bali, Indonesia, 1999, Proceedings: Parkville, Australasian Institute of Mining and Metallurgy, 29-44.

Sillitoe, R.H., 2010, Porphyry copper systems: Economic Geology, 105, 3-41. http://dx.doi. org/10.2113/gsecongeo.105.1.3

Sillitoe, R.H., and Hedenquist, J.W., 2003, Linkages between volcanotectonic settings, ore-fluid compositions, and epithermal precious metal deposits: Society of Economic Geologists Special Publication 10, 315-343. https://doi.org/10.5382/SP.10.16

Sillitoe, R.H., Van Kerkvoort, G., Tolman,J., 2013, Geology of the Caspiche porphyry goldcopper deposit, Maricunga belt, northern Chile: Economic Geology, 108(4), 585-604. https://doi.org/10.2113/econgeo.108.4.585

Stern, R.J., and Gerya, T., 2017, Subduction initiation in nature and models: A review: Tectonophysics, 746,173 - 198. http:// dx.doi.org/10.1016/j.tecto.2017.10.014

Sutcliffe, R., Kuchling, K., Burga, D., Armstrong, T., Yassa, A., Brown, F., Puritch, E., Tortelli, G., Lightwood, G., Brown, D., Gorman, M., 2014, Cerro Quema Project-Pre-feasibility study on the La Pava and Quemita oxide gold deposits 10,000 tpd Heap Leach, Prepared for Pershimco Resources Inc: Reno, U.S.A., P\&E Mining Consultants Inc., Golder Associates Inc., Kappers, Cassiday and Associates, Technical Report, 280 p. https://www.orlamining.com/images/pdf/ reports/Cerro-Quema-Pre-Feasibility-30Jun-14.pdf.pdf

Torró, L., Proenza, J.A., Camprubí, A., Nelson, C.E., Domínguez, H., Carrasco, C., Reynoso-Villafaña, R., Melgarejo, J.C., 2017a, Towards a unified genetic model for the Au-Ag-Cu Pueblo Viejo district, central Dominican Republic: Ore Geology Reviews,
89, 463-494. https://doi.org/10.1016/j. oregeorev.2017.07.002

Torró, L., Camprubí, A., Proenza, J.A., León, P., Stein, H.J., Lewis, J.F., Nelson, C.E., Chavez, C., Melgarejo, J.C., 2017b, Re-Os and U-Pb geochronology of the Doña Amanda and Cerro Kiosko deposits, Bayaguana district, Dominican Republic: Looking down for the porphyry Cu-Mo roots of the Pueblo Viejotype mineralization in the island-arc tholeiitic series of the Caribbean: Economic Geology, 112(4), 829-853. https://doi.org/10.2113/ econgeo.112.4.829

Wegner, W., Wörner, G., Harmon, R.S., Jicha, B.R., 2011, Magmatic history and evolution of the Central American land bridge in Panama since Cretaceous times: Geological Society of America Bulletin, 123(3-4), 703724. https://doi.org/10.1130/b30109.1

Whattam, S.A., 2018, Primitive magmas in the early Central American volcanic arc system generated by plume-induced subduction initiation: Frontiers in Earth Science, 6, Article 114, https://doi.org/10.3389/ feart.2018.00114

Whattam, S.A., and Stern, R.J., 2015, Late Cretaceous plume-induced subduction initiation along the southern margin of the Caribbean and NW South America: The first documented example with implications for the onset of plate tectonics: Gondwana Research, 27(1), 38-63. https://doi. org/10.1016/j.gr.2014.07.011

Whattam, S.A., Montes, C., McFadden, R.R., Cardona, A., Ramirez, D., Valencia, V., 2012, Age and origin of earliest adakiticlike magmatism in Panama: Implications for the tectonic evolution of the Panamanian magmatic arc system: Lithos, 142-143, 266-244. https://doi.org/10.1016/j. lithos.2012.02.017

White, N.C., 1991, High-sulfidation epithermal gold deposits; characteristics and a model for their origin: Geological Survey of Japan Report 227, 9-20. 
Wörner, G., Harmon, R.S., Wegner, W., 2009, Geochemical evolution of igneous rocks and changing magma sources during the formation and closure of the Central American land bridge of Panama: Geological Society of America Memoir 204, 183-196. https://doi.org/10.1130/2009.1204(08)

Wright, J.E., and Wyld, S.J., 2011 . Late Cretaceous subduction initiation on the east-ern margin of the Caribbean-Colombian Oceanic Plateau: one Great Arc of the Caribbean (?). Geosphere, 7(2), 468-493. https://doi. org/10.1130/ges00577.1

Yang, K., Huntington, J.F., Mason, P., Phillips, R.N., 1997, Spectral analysis of samples from Cerro Quema and La Pava Au-Cu prospects, Panama: New South wales, Australia, CSIRO Exploration and Mining report 138R, 7 p. 